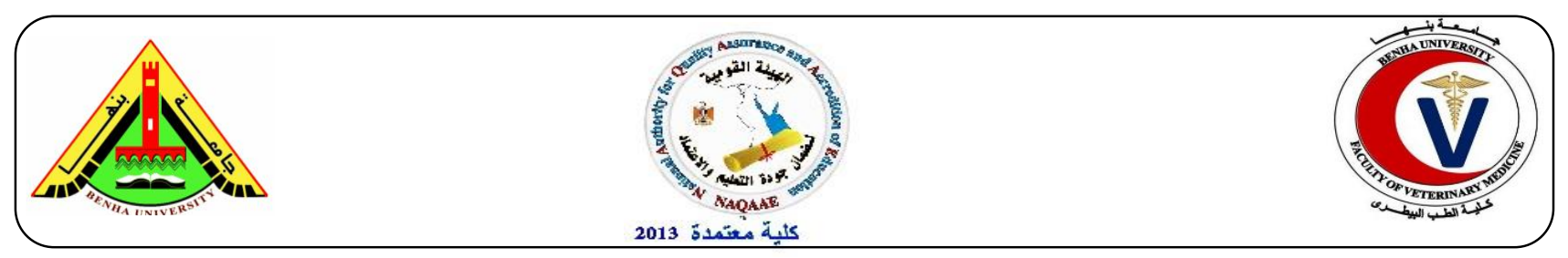

\title{
Detection of Staphylococcus aureus and enterotoxin genes from meat products by using conventional and modern identification methods
}

\author{
Ola Younis ${ }^{1}$, Hemmat, M. Ibrahim ${ }^{1}$, Mohamed Hassan', Reham Amin ${ }^{1}$, Ahmed A. Maarouf ${ }^{2}$ \\ ${ }^{1}$ Department of Food Hygiene and Control, Faculty of Veterinary Medicine, Benha University \\ ${ }^{2}$ Department of Food Hygiene, Animal Health Research Institute, Benha Branch.
}

\begin{abstract}
A B S T R A C T
One hundred meat product samples (minced meat, kofta, burger and sausage, 25 of each) were collected and examined for bacteriological evaluation and detection of Staphylococcus aureus by conventional bacteriological methods and by polymerase chain reaction PCR. The mean value of $S$. aureus counts cfu/g were $0.63 \times 10^{2} \pm 0.19 \times 10, \quad 0.17 \times 10^{2} \pm, \quad 0.96 \times 10^{2} \pm 0.06 \times 10^{2}$ and $1.1 \times 10^{2} \pm 0.15 \times 10^{2}$ respectively. Concerning S.aureus, bacteriological results revealed that the prevalence in minced meat, kofta, burger and sausage was $16 \%, 12 \%, 16 \%, 20 \%$, respectively. In addition, 5 samples out of 100 ones were unaccepted as they were exceeded the permissible limit of E.O.S 2005. Moreover, four random positive and negative S. aureus samples were reexamined by polymerase chain reaction (PCR) and just one sample was negative by the bacteriological method for S. aureus showed positive results with PCR. Multiplex Polymerase Chain Reaction (m-PCR) was applied for detection of genes responsible for enterotoxins production (sea, seb, sec, sed and see) from identified coagulase positive Staphylococcus aureus. They were detected in the examined minced meat and sausage samples.
\end{abstract}

Keywords: Meat products; S. aureus; clfA; enterotoxin; m-PCR.

(http://www.bvmj.bu.edu.eg) (BVMJ-36(2): 229-237, 2019)

\section{INTRODUCTION}

The increasing number and severity of food poisoning outbreaks worldwide have considerably increased public awareness concerning food (Forsythe, 2008), particularly meat and meat products which are one of the most important sources of human infections with different foodborne pathogens (Norrung, et al., 2009). However, meat and meat products continue to be an important food group in the diet for many consumers (Speedy, 2003). Staphylococcus aureus is one of the most pathogenic species and it is responsible for the third of food-borne illness in the world (Normanno et al., 2007). When staphylococci contaminate food, they produce some enzymes which are implicated with the ability of invasiveness and some of extracellular substances are heat stable enterotoxins. Extensive cooking can kill the bacteria however the toxins may not be destroyed as a results of most of them are genebased i.e. they can be carried on the plasmid (Prescott et al., 2005). The Staphylococcal enterotoxins (SEs) are responsible for the 
symptoms associated with Staphylococcal food poisoning (Llewelyn and Cohen, 2002). Microbiological assessment is important to determine the safety and quality of food. In the past isolation and identification of microorganisms were depend on cultural techniques. These methods are the most reliable and accurate in the detection of foodborne pathogens. However, they are labor intensive, have long processing times and are costly. The major disadvantage to the current methodology is that it can take 2- 3 days for any results to show up and up to ten days for confirmation (Jasson et al., 2010). Multiplex polymerase chain reaction $\mathrm{m}-\mathrm{PCR}$ is a powerful technique and has application in the detection of pathogens in food samples. mPCR is an advantage against the culturing methods as you will be able to use different amounts of selective DNA in one PCR reaction. Recent reports have shown that $\mathrm{m}$ PCR greatly improves specificity and sensitivity for the detection of pathogens (Huang et al., 2009).

The multiplex PCR assay for detection of Staphylococcal enterotoxins genes (SEA, SEB, $S E C, S E D$ and $S E E$ ) was developed and proved to be a specific, sensitive, and rapid method. (Zschock et al., 2005). Therefore the current study was planned out throw light on the count and also the incidence of $S$. aureus followed by PCR confirmation and m-PCR identification of enterotoxigenic strains in meat products (minced meat; kofta; burger and sausage) sold in supermarkets at Kaliobia Governorate.

\section{Materials and methods}

\subsection{Collection of samples:}

A total of 100 random samples of meat products; minced meat; beef kofta; beef burger and sausage (25 for each), were purchased from different supermarkets at Kaliobia Governorate, Samples were submitted to the lab in Animal Health Research Institute for bacteriological examination to detect the incidence of Staphylococcus aureus and its enterotoxin genes by using conventional and modern identification methods and evaluate the hygienic health hazard of them with Staphylococci.

\subsection{Bacteriological examination:}

\subsubsection{Preparation of samples (APHA, 2001)}

2.2.2. Determination of Staphylococci and $S$. aureus counts (FDA, 2001).

\subsubsection{Isolation and identification of suspected}

S. aureus: according to Quinn et al (2002), the samples were cultured for isolation of $\mathrm{S}$. aureus onto peptone water for 24 hours at $37^{\circ} \mathrm{C}$ and then a loopful was taken and cultured onto mannitol salt agar and then onto Baird parker medium. All inoculated plates were incubated at $37^{\circ} \mathrm{C}$ for $24-48$ hours then colonies were identified. The colonies characterized by circular, smooth, convex, moist, $2-3 \mathrm{~mm}$ in diameter, gray to jet-black, frequently with light-colored (offwhite) margin, surrounded by opaque zone and frequently with an outer clear zone. All suspected colonies are tested and confirmed biochemically and coagulase activities.

\subsection{Polymerase Chain Reaction (PCR):}

Using polymerase chain reaction (PCR) in 4 random sample for Polymerase Chain Reaction (PCR) of 4 random S. aureus meat products samples two positive (minced meat- sausage) and two negatives (burger- kofta).

2.4. Multiplex polymerase chain reaction ( $m$ $P C R)$ : for detection of classic enterotoxin genes (A, B, C, D and E) of positive S. aureus meat products samples (minced meat, burger and kofta) one sample of each.

DNA extraction and purification direct from the meat products samples, following QIAamp DNA Mini Kit (Catalogue no.51304), Emerald Amp GT PCR master mix (Takara) with Code No. RR310A, $1.5 \%$ agarose gel electrophoreses (Sambrook et al., 1989) using the Primers sequence, target genes amplicons sizes and cycling conditions showed in Tables (1) and (2). 


\subsection{Statistical analysis:}

Data obtained were analyzed according to Snedecor and Cochran (1969) using the computer software program (SPSS, 2001).

\section{RESULTS}

The results of the examined meat products (minced meat, kofta, burger and sausage) are presented in Tables (1-4) and Figures (1-2). The results of bacteriological examination of meat products revealed that Staphylococcus counts were highest in minced meat then burger and kofta then sausage. While, Staphylococcal aureus count was highest in sausage then burger and minced meat then kofta, in which the incidence of co-agulase positive Staph. aureus is highest in sausage then burger and minced meat then kofta.

The results of molecular identification showed that three out of Four random sample (one of each product) (two positive and two negative) were positive for $S$. aureus by using uniplex $P C R$. In addition, the three positive $S$. aureus samples were reexamined by $\mathrm{m}-\mathrm{PCR}$ for detection of different enterotoxins and the results revealed that one isolate carrying $\mathrm{Seb}$ gene, and other carrying Sed gene, while one negative for all enterotoxins.

Table1: Cycling conditions of S.aureus primers during cPCR

\begin{tabular}{cccccccc}
\hline Target & $\begin{array}{c}\text { Cyclic } \\
\text { condition }\end{array}$ & $\begin{array}{c}\text { Primary } \\
\text { denaturation }\end{array}$ & $\begin{array}{c}\text { Secondary } \\
\text { denaturation }\end{array}$ & Annealing & Extension & $\begin{array}{c}\text { No. of } \\
\text { cycles }\end{array}$ & $\begin{array}{c}\text { Final } \\
\text { extension }\end{array}$ \\
\hline \multirow{5}{*}{ S. aureus } & $\begin{array}{c}\text { For } \\
\text { detection of }\end{array}$ & $94^{\circ} \mathrm{C}$ & $94^{\circ} \mathrm{C}$ & $55^{\circ} \mathrm{C}$ & $72^{\circ} \mathrm{C}$ & 35 & $72^{\circ} \mathrm{C}$ \\
& $\begin{array}{c}\text { S. } \text { aureus } \\
\text { For }\end{array}$ & $5 \mathrm{~min}$. & $30 \mathrm{sec}$. & $40 \mathrm{sec}$. & $45 \mathrm{sec}$. & & $10 \mathrm{~min}$. \\
& $\begin{array}{c}\text { detection of } \\
\text { enterotoxins }\end{array}$ & $54^{\circ} \mathrm{C}$ & $94^{\circ} \mathrm{C}$ & $57^{\circ} \mathrm{C}$ & $72^{\circ} \mathrm{C}$ & 35 & $72^{\circ} \mathrm{C}$ \\
\hline
\end{tabular}

Table 2: A detailed descriptions of the designed oligonucleotide primers sequences used

\begin{tabular}{|c|c|c|c|c|c|}
\hline Target & $\begin{array}{l}\text { Prime } \\
\mathrm{r}\end{array}$ & Gene & Sequence $\left(5^{\prime}-3^{\prime}\right)$ & $\begin{array}{c}\text { Amplified } \\
\text { product }\end{array}$ & Reference \\
\hline \multirow{6}{*}{ S. aureus } & $\begin{array}{l}\mathrm{F} \\
\mathrm{R}\end{array}$ & clfA & $\begin{array}{l}\text { GCAAAATCCAGCACAACAGGAAACGA } \\
\text { CTTGATCTCCAGCCATAATTGGTGG }\end{array}$ & 638 bp & $\begin{array}{l}\text { Mason et al., } \\
\quad 2001\end{array}$ \\
\hline & $\begin{array}{l}\mathrm{F} \\
\mathrm{R}\end{array}$ & Sea & $\begin{array}{l}\text { GGTTATCAATGTGCGGGTGG } \\
\text { CGGCACTTTTTTCTCTTCGG }\end{array}$ & $102 \mathrm{bp}$ & \\
\hline & $\begin{array}{l}\mathrm{F} \\
\mathrm{R}\end{array}$ & $\mathrm{Seb}$ & $\begin{array}{l}\text { GTATGGTGGTGTAACTGAGC } \\
\text { CCAAATAGTGACGAGTTAGG }\end{array}$ & 164 bp & \multirow{4}{*}{$\begin{array}{c}\text { Mehrotra et } \\
\text { al., } 2000\end{array}$} \\
\hline & $\mathrm{F}$ & $\mathrm{Sec}$ & AGATGAAGTAGTTGATGTGTATGG & $451 \mathrm{bp}$ & \\
\hline & $\begin{array}{l}\mathrm{F} \\
\mathrm{R}\end{array}$ & Sed & $\begin{array}{c}\text { CCAATAATAGGAGAAAATAAAAG } \\
\text { ATTGGTATTTTTTTTCGTTC }\end{array}$ & $278 \mathrm{bp}$ & \\
\hline & $\begin{array}{l}\mathrm{F} \\
\mathrm{R}\end{array}$ & $\mathrm{See}$ & $\begin{array}{l}\text { AGGTTTTTTCACAGGTCATCC } \\
\text { CTTTTTTTTCTTCGGTCAATC }\end{array}$ & 209 bp & \\
\hline
\end{tabular}


Younis et al. (2019). BVMJ-36(2): 229-237

Table 3: Total Staphylococci counts/g in the examined samples of meat products $(n=25)$

\begin{tabular}{|c|c|c|c|c|c|}
\hline \multirow{2}{*}{ Samples } & \multicolumn{2}{|c|}{ Positive } & \multirow{2}{*}{ Min. } & \multirow{2}{*}{ Max. } & \multirow{2}{*}{ Mean \pm SEM $* * *$} \\
\hline & No. & $\%$ & & & \\
\hline Minced Meat & 25 & 100 & $0.3 \times 10^{2}$ & $3.1 \times 10^{3}$ & $1.2 \times 10^{3} \pm 1.8 \times 10^{2 \mathrm{a}}$ \\
\hline Kofta & 25 & 100 & $1.0 \times 10^{2}$ & $5.3 \times 10^{3}$ & $1.06 \times 10^{3} \pm 2.2 \times 10^{2 \mathrm{a}}$ \\
\hline Burger & 24 & 96 & $0.1 \times 10^{2}$ & $2.8 \times 10^{3}$ & $1.09 \times 10^{3} \pm 1.7 \times 10^{2 \mathrm{a}}$ \\
\hline Sausage & 25 & 100 & $0.1 \times 10^{2}$ & $2.8 \times 10^{3}$ & $0.97 \times 10^{3} \pm 1.8 \times 10^{2 a}$ \\
\hline
\end{tabular}

N.B.:- There was no sig. difference between different meat products.

Table 4: Staphylococcus aureus counts/gm. in the examined samples of meat products $(\mathrm{n}=25)$

\begin{tabular}{cccc}
\hline Samples & Min. & Max. & Mean \pm SEM \\
Minced Meat & $0.33 \times 10^{2}$ & $1.2 \times 10^{2}$ & $0.63 \times 10^{2} \pm 0.19 \times 10^{2 \mathrm{ab}}$ \\
Kofta & $0.05 \times 10^{2}$ & $0.25 \times 10^{2}$ & $0.17 \times 10^{2} \pm 0.06 \times 10^{2 \mathrm{~b}}$ \\
Burger & $0.5 \times 10^{2}$ & $1.6 \times 10^{2}$ & $0.96 \times 10^{2} \pm 0.24 \times 10^{2 \mathrm{a}}$ \\
Sausage & $0.72 \times 10^{2}$ & $1.5 \times 10^{2}$ & $1.1 \times 10^{2} \pm 0.15 \times 10^{2 \mathrm{a}}$ \\
\hline
\end{tabular}

N.B. Different letter within the same column indicates sig. difference.

Table 5: Acceptability of Total S. aureus counts in the examined samples of meat products $(n=25)$

\begin{tabular}{cccccc}
\hline & & \multicolumn{2}{c}{ Accepted } & \multicolumn{2}{c}{ Unaccepted } \\
samples & \multicolumn{2}{c}{ samples } \\
Samples & PL* & No. & $\%^{*}$ & No. & $\%^{*}$ \\
Minced Meat & $10^{2}$ & 24 & 96 & 1 & 4 \\
Kofta & $10^{2}$ & 25 & 100 & 0 & 0 \\
Burger & $10^{2}$ & 23 & 92 & 2 & 8 \\
Sausage & $10^{2}$ & 23 & 92 & 2 & 8 \\
\hline
\end{tabular}

*permissible limits according to EOS (2005).

Table 6: Incidence of S.aureus in the examined meat products samples $(\mathrm{n}=25)$

\begin{tabular}{ccc}
\hline Samples & \multicolumn{2}{c}{ Positive S.aureus } \\
& No. & $\%$ \\
\hline Minced Meat & 4 & 16 \\
Kofta & 3 & 12 \\
Burger & 4 & 16 \\
Sausage & 5 & 20 \\
Total & 16 & 16 \\
\hline
\end{tabular}




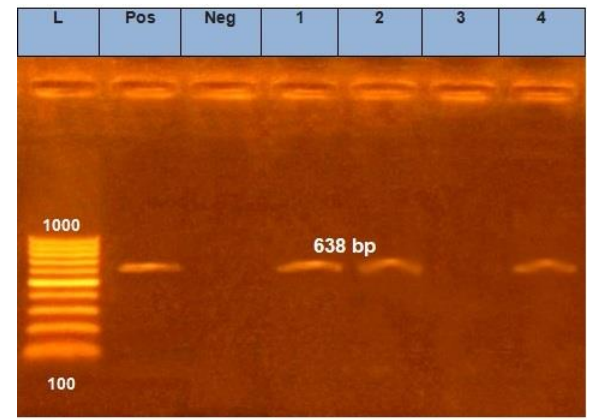

Fig.1. Agarose gel electrophoresis showing PCR products of clfA gene (638bp) specific for characterization of S.aureus. Lane L: 100-1000 bp DNA Ladder. Neg.: Negative control (Salmonella reference: ATCC14028). Pos.: Positive control (S. aureus reference: ATCC25923 at 638 bp). Lane 1; 2\&4: Positive $S$. aureus (minced meat, sausage and burger) one of each.Lane 3: Negative $S$. aureus.

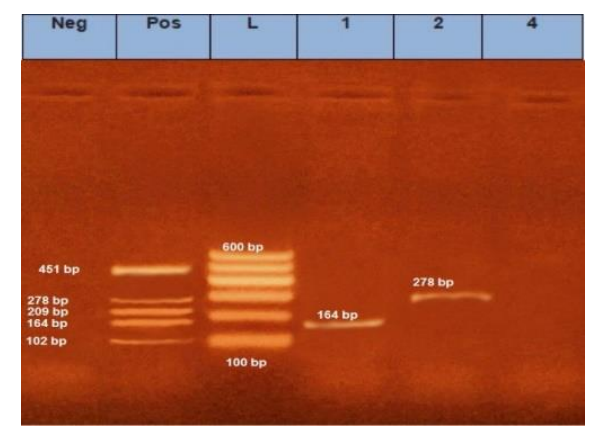

Fig.2. Agarose gel electrophoresis of multiplex PCR of sea (102), seb (164), sec (451), sed (279) and see (209) enterotoxin genes for characterization of s.aureus isolated from Minced meat, Burger and sausage (one from each product). Lane L: 100-600 bp DNA Ladder. Neg.: Negative control. Pos.: Positive control for sea, seb, sec, sed and see. Lane 1: Positive S. aureus strain for seb gene (minced meat). Lane 2: Positive S. aureus strain for sed gene (sausage). Lane 4: Negative S. aureus strain for enterotoxins (burger).

\section{DISCUSSION}

The foodborne pathogens are able to cause serious public health problems, particularly in developing countries where they cause a high level of morbidity and mortality rates. Quick, sensitive, specific and simple techniques for detection of the foodborne pathogens are required for the effective implementation of food safety. Polymerase chain reaction (PCR) has become an indispensable tool in molecular diagnostics and can be very efficiently used in rapid detection of food-borne pathogens (Pinto et al., 2005).

\subsection{Total Staphylococcus count:}

Staphylococci were normally inhabitant in animal and man, as a results of their ubiquitous occurrence in nature, they were found in numerous raw foods, at the meanwhile foodborne illness from Staphylococcus enterotoxins remains a major problem worldwide (Normanno et al., 2005). Staphylococcus counts (cfu/g) of the examined meat products (minced meat; kofta; burger and sausage) came in agreement with those reported by Abd El-Fatah-Rabab (2015). Meanwhile, a lower results were recorded by Karaboz and Dincer (2002) and Gibriel et al. (2007).

Moreover, the statistical results revealed that there was no significant difference $(\mathrm{P}>0.05)$ of Staphylococci counts between meat product samples (minced meat, beef kofta, burger and sausage. These results came in accordance 
with that obtained by Maarouf and NassifMarionette (2008) and Abd El- Salam-Azza et al. (2014).

\subsection{Staphylococcus aureus count:}

The presence of $S$. aureus in foods commonly indicates direct contamination from worker's hands with abrasion and wounds or inadequately cleaned equipment resulting in $S$. aureus intoxication. Accordingly, the total $S$. aureus count can be taken as an indicator of sanitary degree under which the meat and its products are processed and handled (potter, 2001). The recorded results in (Table, 4) revealed that, mean values of the examined meat products (minced meat; beef kofta; beef burger and sausage) samples were $0.63 \times 10^{2} \pm 0.19 \times 10^{2 \mathrm{ab}} ; \quad 0.16 \times 10^{2} \pm 0.06 \times 10^{2 \mathrm{~b}}$; $0.96 \times 10^{2} \pm 0.24 \times 10^{2 \mathrm{a}}$ and $1.1 \times 10^{2} \pm 0.15 \times 10^{2 \mathrm{a}}$, respectively. These results disagreed with those of Oluwafemi and Simisaye (2006) Gibriel et al. (2007) who recorded higher $S$. aureus counts in examined samples.

Results obtained in the table (5) revealed that $4 \%, 0 \%, 8 \%$ and $8 \%$, respectively of minced meat, kofta, beef burger and sausage were exceeded the permissible limit according to E.O.S. (2005). So that the samples which exceeding the permissible limit represent a potential health risk at which under favorable condition, $S$. aureus can proliferate and produce enterotoxin causing SFP.

\subsection{Isolation of Staphylococcus aureus}

As shown in Table (6), the percentages of $S$. aureus isolated from the examined minced meat, kofta; burger and sausage samples were $16 \%, 12 \%, 16 \%, 20 \%$, respectively.

The obtained results of $S$. aureus in the examined samples were nearly similar to those of Omar et al., (2009) and Soultos et al. (2003), and lower than those obtained by Vorster et al. (1994) and El-Khateib, (1997).
In general contamination with S.aureus may occur during the preparation, packaging, transportation and storage of meat products in supermarkets or directly from infected foodproducing animals. However the low percentage of $S$. aureus in kofta and burger may be due to the addition of spices during manufacture and good hygiene.

\subsection{Polymerase Chain Reaction (PCR).}

PCR offers sensitive and specific detection of pathogens. Within the last ten years, several authors have proposed the use of m-PCR for the detection of foodborne pathogens to replace the conventional methods. They are rapid, easy to handle, sensitive and specific and therefore constitute very valuable tools for routine applications. This study showed that the PCR technique was very convenient to take DNA templates directly from the meat products samples after DNA extraction and there is no need to take from the culture as it time-consuming, labour intensive and very costly as reported by Chen et al., (2012) and Kim et al., (2014) who examined directly from food samples without the use of bacterial cultures but with different primers used in this study unlike Latha et al., (2014) who examined their PCR technique by the use of bacterial culture.

Four random $S$. aureus samples (two positives and two negatives) by the conventional method, were reexamined by PCR, there was great agreement between results of conventional method for and PCR technique in three random samples (2 positive and 1 negative), while one sample was negative by conventional method for S. aureus, showed positive results with PCR (false negative) as in fig. (1).

This result clarified the high sensitivity of the PCR technique in detection the false negative results of the traditional microbiological culture method. Similar results were obtained 
by Chen et al., (2012) who detected a false negative result (negative by conventional method and positive by m-PCR.

The false negative result may due to the low number of bacterial load which can't be detected by microbiological assay. Also, inhibition of some microbes to selective microbe appearance on the media. So the $\mathrm{m}$ PCR assay has the potential to be used in routine diagnostic laboratories and also as a rapid screening tool in food testing laboratories to identify food samples quickly especially in case of outbreaks.

\subsection{Multiplex PCR for detection of classic enterotoxin.}

It was clear that 3 isolates of examined minced meat, burger and sausage samples (one of each), were subjected to multiplex PCR for detection of $S$. aureus classic enterotoxin genes and the results were as follow: isolate for minced meat sample mostly harbored (1) seb. Meanwhile, isolate for sausage sample harbored (1) sed gene and the isolate of burger sausage sample was negative for all classic enterotoxin genes fig. (2).

PCR is rapid and specific method for detection of different food borne pathogen in meat products samples. It gives the ability to detect bacteria cells within a little time and PCR was demonstrated to be accurate methods for identification.

\section{REFERENCES}

Abd EL-fatah, Rabab, R. 2015. Bacteriological status of some ready to eat meat and poultry meals in Benha City. M.V.Sc. Thesis (Meat Hygiene), Fac. Vet. Medicine, Benha Univ. Egypt.

Abdaslam - Azza S.; Hassan, M. A.; Kaheel, H. A.; Abobaker, T. M.; Alnourain, T. H.; Hamdan, H. A.; Gokul Shankar, S. and Thambirajah, J., 2014. Isolation of
Escherichia coli $\mathrm{O}_{157}$ and other foodborne pathogens from meat products and their susceptibility to different antimicrobial agents. Current Research in Microbiology and Biotechnology, 2 (3): 391-397.

APHA"American Public Health Association", 2001. "Compendium of Methods for the Microbiological Examination of Foods". 4th Ed. F.P. Downes and K. Ito (editors), APHA. Washington D.C., USA.

Chen, J., Tang, J., Liu, J., Cai, Z., Bai, X., 2012. Development and evaluation of a multiplex PCR for simultaneous detection of five foodborne pathogens. Journal of Applied Microbiology.112: 823-830.

El-Khateib, T., 1997. Microbiological status of Egyptian salted meat and fresh sausage. Journal of Food Safety, 17(3):141-150.

EOS "Egyptian Organization for Standardization and Quality Control", 2005: EOS, NO, 1114/2005.

FDA, "Food and Drug Administration", 2001. Food and Drug Administration Center for Food safety and applied nutrition: (www.FDA.org.).

Gibriel, A. Y., Ebeid, H. M., Khalil, H. I. and Abdel-Fattah, A. A., 2007. Application of Monascus purpureus pigments produced using some food industry wastes in beef sausage manufacture. Egyptian Journal of Food Science. 35: 27-45.

Huang, X., Feng, Q., Qian, Q., Zhao, Q., Wang, L., Wang, A., Guan, J., Fan, D., Weng, Q., Huang, T., Dong, G, Sang, T. and Han, B., 2009. High-Throughput Genotyping by Whole-Genome Resequencing. Genome research 19: 1068-76.

Jasson, V., Jacxsens, L., Luning, P., Rajkovic, A., Uyttendaele, M. 2010. Review. Alternative microbial methods: An 
overview and selection criteria. Food Microbiology, 27:710-730.

Karaboz, I. and Dincer, B. 2002. Microbiological investigation on some of the commercial frozen meat in IZMIR. Turkish Electronic J. Biotechnology, Special issue: 18-23.

Kim, J., Rhim, S., Kim, K., Paik, H., Lee, J. 2014. Simultaneous Detection of Listeria monocytogenes, Escherichia coli O157:H7, Bacillus cereus, Salmonella spp., and Staphylococcus aureus in Low fatted Milk by Multiplex PCR. Korean J. Food Science, 34(5): 715-716.

Latha, C.C.A., Sunil, B.V.A., Jolly, D. 2014. Multiplex PCR assay for the simultaneous detection of four common food pathogens in meat. Journal of Foodborne and Zoonotic Diseases 2(3): 45-49.

Llewelyn, M. and Cohen, J. 2002. Super antigens: Microbial agents that corrupt immunity. Lancet. Infect. Dis., 2: 156162.

Maarouf, A.A. and Nassif-Marionette. 2008. Bacteriological studies on frozen cow meat and some meat products at Benha city. Journal of the Egyptian Vet. Med. Assoc., 68 (1):129-141.

Mason, W.J.; Blevins, J.S.; Beenken, K.; Wibowo, N.; Ojha, N. And Smeltzer, M.S. 2001: multiplex PCR protocol FOR THE diagnosis of staphylococcal infection. Journal of Clinical Microbiology, Vol. 39, No. 9, p. 33323338.

Mehrotra, M.; WANG, G. and, Johnson, W.M. 2000: Multiplex PCR for Detection of Genes for Staphylococcus aureus Enterotoxins, Exfoliative Toxins, Toxic Shock Syndrome Toxin 1, and Methicillin Resistance. Journal of Clinical Microbiology.Vol. 38, No. 3.

Normanno, G.; Firinu, A.; Virgilio, S.; Mula, G.; Damprosio, A.; Poggiu, A.;
Decastelli, L.; Mioni, R., Scovta, S.; Bolzonr, G.; Bartoli, M.; Zuccon, F.; Pirino, T.; Sias, S.; Parisr, A.; Quaglia, N. C. and Celano, G. V. 2005. Coagulase-positive staphylococci and Staphylococcus aureus in food products marketed in Italy .International. J. Food Microbiology., 98(1):73-79.

Normanno, G.; La Salandra, G.; Dambrosio, A.; Quaglia, N.C. ; Corrente, M.; Parisi, A.; Santagada, G.; Firin, U. A.; Crisetti, E. and Celano, G. V. 2007. Occurrence, characterization and antimicrobial resistance of enterotoxigenic Staphylococcus aureus isolated from meat and dairy products. International J. Food Microbiology, 115: 290-296.

Norrung, B., Andersen, J. K., Buncic, S. 2009. Safety of Meat and Processed Meat. Food Safety and Nutrition. Pp.: 3-29. SBN 978-0-387-89026-5.

Oluwafemi, F. and Simisaye, M., 2006. Extent of microbial contamination of sausages sold in two Nigerian cities. African J. Biomedical Research, 9: 133-136.

Omar, H.S., Ikbal, A.A., Entesar. R.A., 2009. Extraction of Staphylococcus aureus toxin from minced meat in Mosul City. The Iraq J. for Vet Med 23 (1): 27-32.

Pinto, B., Chenoll, E., Aznar, R., 2005. Identification and typing of foodborne Staphylococcus aureus by PCR-based techniques. Systematic Applied Microbioliogy, 28: 340-352.

Potter, N. N., 2001. Food Science, 3rd Ed. The AVI Publishing Co., INC. New York, USA.

Prescott, M., Harley, P. and Klein, D. A., 2005. Microbiology, $6^{\text {th }}$ Ed. McGraw Hill. New York U.S.A.: p. 910.

Quinn, P. J., Markey, B. K., Carter, M. E., Donnelly, W. J. C., Leonard, F. C. and Maguire, D. 2002. Veterinary microbiology and microbial disease. 
Iowa State Univ. Press, Blackwell Science Ltd, 26-36: 84-96.

Sambrook, J., Fritscgh, E.F., and Mentiates, 1989. Molecular coloning. A laboratory manual.Vol., Cold spring Harbor Laboratotry press, New York.

Snedecor, G.W. and Cochran, W.G., 1969. Statistical Methods, 6th Ed. Iowa State University Press, Asmes, USA.

Soultos, N., Abrahim, A.,and Abrosiadis, I. 2003. Incidence of some food bornbacterial pathogens in traditional sausages produced in Northen Greece. Archiv. Furer. Lebensmittel. Hygiene, 54(3):55-57.

Speedy, A. W. 2003. Global Production and Consumption of Animal Source Foods. J. Nutrition. 133. Pp.: 4048S-4053S.

SPSS for windows, Version: 11 (19 September 2001). Copyright SPSS Inc. 19892001. All rights reserved.

Vorster, S.M., Greebe, R.P., Nortje, G.L. 1994. Incidence of Staphylococcus aureus and Escherichia coli in ground beef, broilers and processed meat in Pretoria, South Africa. Journal of Food Protection., 57(4):305-310.

Zschock, M., Kloppert, B., Wolter, W., Hamann, H.P. and Lammler, C.H., 2005. Pattern of enterotoxin genes seg ,seh,sei and sej positive Staphylococcus aureus isolated from bovine mastitis. Veterinary Microbiology 108(3-4): 243. 